\title{
Artykuly
}

STUDIA ORIENTALNE 2017, $\mathrm{nr} 2$ (12)

Dalzar Nashwan Salem

ISSN 2299-1999

\section{Tożsamość zbiorowa imigrantów z Bliskiego Wschodu w wybranych państwach Unii Europejskiej}

\section{Tożsamość społeczna, tożsamość zbiorowa}

Tożsamość społeczna to prawdziwe ja człowieka, to także świadomość 1 własnej spójności w czasie, przestrzeni, jak też w poszczególnych okresach życia i w sytuacjach społecznych, oraz świadomość pełnionych ról. Ponadto tożsamość społeczna przejawia się w świadomości własnej odrębności, indywidualności i niepowtarzalności ${ }^{1}$.

Przejawem tożsamości społecznej jest pełnienie ról społecznych, czyli posiadana płeć kulturowa. W praktyce oznacza to zbiór cech, zachowań, stereotypów i ról płciowych, które przypisuje się kobietom lub mężczyznom należącym do danej kultury. Cechy takie nabywa się w drodze socjalizacji, a więc trzeba je nabyć od grupy, a nie z nimi się urodzić - tj. je odziedziczyć. Co więcej, nie wynikają one bezpośrednio z biologicznych różnic w zakresie budowy ciała pomiędzy płciami, czyli dymorfizmu płciowego ${ }^{2}$.

Tożsamość społeczna pojmowana jest więc jako przynależność do danej grupy i kategorii. Dzieje się to za sprawą afiliacji. Natomiast każdy akt afiliacji społecznej wiąże się z wyborem tożsamości i odwrotnie. Tożsamość wymusza w celu przetrwania swoiste afiliacje społeczne ${ }^{3}$.

1 A. Białowąs, Filozoficzne aspekty wykorzystywania informacyjno-komunikacyjnych technologii w procesie ksztatcenia i samokształcenia, [w:] Nowe media a tradycyjne środki przekazu, red. P. Drzyzga, Kraków 2007, s. 142-144.

2 W. Paluchowski, Internet a psychologia. Możliwości i zagrożenia, Warszawa 2009, s. 58-59 .

3 W. Pawliczuk, Koncepcje antropologiczno-kulturowe adolescencji, „Postępy Nauk Medycznych" 2006, nr 6, s. 177. 
Trzeba jednak zaznaczyć, że odnosząc się do tożsamości w wymiarze ogólnym, wskazuje się na kilka jej rodzajów. Ich specyfikacja została przedstawiona w poniższej tabeli.

Tabela 1. Rodzaje tożsamości

\begin{tabular}{|c|c|c|}
\hline Lp. & Rodzaj tożsamości & Charakterystyka danego rodzaju \\
\hline 1. & Jednostkowa & $\begin{array}{l}\text { Dotyczy poszukiwania odpowiedzi na pytanie o to, kim dany człowiek jest. Dlate- } \\
\text { go też warunkuje relacje z samym sobą, ale również z jej otoczeniem. }\end{array}$ \\
\hline 2. & Społeczna & $\begin{array}{l}\text { Reguluje kwestie, które są związane z przypisywaniem cech jednostce, za co od- } \\
\text { powiada otoczenie. Dzięki temu częśc cech jest przypisywana automatycznie } \\
\text { przez innych członków grupy. }\end{array}$ \\
\hline 3. & $\begin{array}{l}\text { Zbiorowa, określa- } \\
\text { na również mianem } \\
\text { grupowej oraz ko- } \\
\text { lektywnej }\end{array}$ & $\begin{array}{l}\text { Odczucia w zakresie tożsamości różnych zbiorowości, do czego dodatkowo wy- } \\
\text { korzystuje się odczucia jednostkowe. Stąd też tego rodzaju tożsamość tworzona } \\
\text { jest w obrębie rodzin, plemion, narodów, a więc grup, które mają poczucie odrę- } \\
\text { ności od innych. }\end{array}$ \\
\hline
\end{tabular}

Źródło: Opracowanie własne na podstawie: M. Golka, Czym jest tożsamość?, http://socjologia.amu.edu.pl/isoc/userfiles/33/Czym_jest_tozsamosc.pdf [dostęp: 11.07.2016].

W odniesieniu do niniejszego opracowania kluczowe znaczenie ma tożsamość zbiorowa. Jak zauważa Z. Bokszański, tożsamość zbiorowa staje się w istocie odkrywaniem samego siebie, poznawaniem sensu własnego istnienia. Można zatem wspomnieć, iż takie ujęcie tożsamości staje się często podstawą opracowania polityk imigracyjnych czy kulturowych ${ }^{4}$. Należy nadmienić, że w literaturze przedmiotu występuje wiele definicji pojęcia „tożsamość zbiorowa”, co jest wynikiem faktu, iż pojęciem tym zajmuje się wiele nauk społecznych jednocześnie. Jak zauważa Z. Bokszański, tożsamość zbiorową rozpatrywać można w dwóch podejściach. Pierwsze z nich zakłada, że pojęcie tożsamości zbiorowej jest synonimem grupy, do której się ona odnosi, np. narodu, natomiast drugie podejście zakłada, iż najważniejsze dla tożsamości jest pochodzenie elementów ją tworzących ${ }^{5}$. Dlatego dalsza część analizy będzie się odnosiła tylko do tego rodzaju tożsamości.

Tożsamość kolektywna jest elementem konstytutywnym każdej społeczności. Od stopnia jej utrwalenia i konsolidacji zależy przetrwanie zbiorowości. Jest to czynnik niezwykle istotny, ujawniający swą siłę nie

\footnotetext{
4 Z. Bokszański, Tożsamość zbiorowa, Warszawa 2007, s. 62-63.

5 Ibidem, s. 63-65.
} 
tylko w sytuacjach zagrożenia, ale także w procesach kulturowej adaptacji, szczególnie gdy dochodzi do zderzenia odmiennych i nierzadko skrajnie różnych kultur, co może prowadzić do kryzysu i zakłóceń w samoidentyfikacji. Wydaje się, że w przypadku imigrantów - osób dobrowolnie opuszczających rodzinny kraj - proces ten powinien przebiegać znacznie łagodniej i sprawnej niż w przypadku na przykład przymusowych przesiedleń. Rzeczywistość pokazuje jednak, że utrwalone w imigrantach poczucie tożsamości i więzi z kulturą rodzimą staje się ogromną barierą w procesie przystosowania do nowego otoczenia cywilizacyjnego. Szczególnym przykładem jest tu sytuacja imigrantów z Bliskiego Wschodu, dla których miejscami destynacji stają się kraje europejskie. W kulturze bliskowschodniej, inaczej niż w środowisku europejskim, zależności plemienne, lokalne i regionalne stanowią podstawowy element tożsamości jednostek i grup. Co więcej, w wielu przypadkach są one silniejsze niż poczucie więzi narodowej. Zderzenia dwóch rożnych cywilizacji, a zatem także radykalnie odmiennych tożsamości nie tylko poważnie zaburza, ale i często uniemożliwia proces kulturowej adaptacji ${ }^{6}$.

Muzułmanie odczuwają przynależność do tożsamości religijnej, bardziej niż przynależność do swoich rodzin czy krajów, w których żyją obecnie. Według zachodnich badań to zjawisko jest większe wśród młodych mężczyzn i kobiet muzułmańskich.

Arabsko-islamska kultura odgrywa dużą rolę w kształtowaniu funkcjonowania muzułmanów w Unii Europejskiej. Wpływ ten wywodzi się od kultury arabskiej, arabskich zwyczajów i tradycji, które są silniejsze od zachowań opartych na wierzeniach islamskich?

Wszystkie osoby należące do obu kultur dążą do integracji, ale każda ze stron stoi w tym samym miejscu, uważając, że wartości własne nie pasują do drugiej. Każda wartość stanowi wyzwanie dla drugiej tożsamości. Taka perspektywa i tendencja prowadzi do separacji i oddalenia jednej strony od drugiej. Mimo to, proces asymilacji został przyjęty przez imigrantów muzułmańskich, ale wielu z nich wolałoby zachować tożsamość pierwotną. Wydaje się, że obecna jest tendencja do izolacjonizmu i różnic.

6 I. Grabowska, Movers and Stayers: Social Mobility, Migration and Skills, Frankfurt am Main 2016, s. 73-74.

7 Ibidem, s. 78 . 
Z sondażu przeprowadzonego w 2003 roku przez IPSOS wynika, że 62\% Francuzów, którzy brali udział w badaniu, wierzy, że wartości islamskie nie są zgodne z wartościami Republiki.

W Niemczech, Szwecji, i Francji odbywają się debaty i konferencje dotyczące takich kwestii, jak: hidżab, budowa meczetów, jedzenie halal, otwarcie islamskich szkól, nauczania religii islamskiej w szkołach, rytuały obrzędów pogrzebowych dla muzułmanów. Kontrowersje występują w kwestii praw kobiet i zgodności islamu z wartościami demokratycznymi. Stąd wywodzą się oddziaływania islamu na umysły polityków, intelektualistów i zwykłych obywateli.

W opinii większości obecność islamu stanowi zagrożenie i wyznawanie, np. ze względu na terroryzm, a przed wszystkim na tożsamość muzułmańską i wartości tej religii. Europejczycy niekiedy nazywają to strachem i nienawiścią do islamu. To powoduje, że muzułmanie bardziej trzymają się swojej tożsamości i wartości różnych od wartości uznawanych przez Europejczyków ${ }^{8}$. Odporność na asymilację prowadzi do obecności islamu, a nie do przystosowania się do wspólnoty europejskiej. Czynniki te stanowią barierę dla imigrantów muzułmańskich w Europie. Będzie to wyzwanie dla imigrantów Bliskiego Wschodu'.

Muzułmanie w Europie mają problemy z przyjęciem mentalności i wartości liberalnych, które dotyczą równości kobiet i mężczyzn oraz wolności seksualnej. Te kwestie stanowią wyzwanie dla konwencjonalnie myślących muzułmanów w Europie. Zdecydowana większość muzułmanów, nie uznaje głównego dorobku oświecenia. Świeckie społeczeństwo jest obce myśli islamskiej. Jest to wyzwanie dla muzułmanów w UE, jeśli przyjmą to za punkt wyjścia do przyszłych zmian.

Kolejnym istotnym zagadnieniem w tym obszarze jest kwestia wpływu stereotypów na tożsamość zbiorową. Każda grupa i jej członkowie są narażeni na efekt zagrożenia stereotypem, obawą „członków wyróżniającej się grupy, że ich zachowanie może potwierdzić stereotyp kulturowy"10. Ter-

8 M. Ruhs, W. Eskil, A. Wójcicka, Labour Migration. What's in it for us? Experiences from Sweden, the UK and Poland, Stockholm 2012, s. 135-137.

9 Ibidem, s. 141.

10 A.E. Steel, Stereotype threat and the intellectual test performance of African American, „Journal of Personality and Social Psychology” 1994, Vol. 5, No. 69, s. 794. 
min ten po raz pierwszy w 1995 r. wprowadzili E. Aronson i A.E. Steel po przeprowadzeniu badań nad tym zjawiskiem ${ }^{11}$.

Zagrożenie stereotypem to zjawisko często występujące i dotyczące każdej grupy bez względu na płeć czy wyznanie. Chociaż ten drugi aspekt to element szczególnie przekładający się na przynależność do określonej zbiorowości. Nie mniej jednak w przypadku muzułmanów często określa się ich przez pewien pryzmat stanowiący element stereotypu. „Członkowie grup społecznych są podatni na zagrożenie stereotypem tylko wtedy, gdy uważają za ważną dziedzinę, w której ich grupie przypisuje się niskie osiągnięcia ${ }^{12}$. Ponadto przy zagrożeniu stereotypem zostaje zmieniona, a do tego utrwalona pewna postawa. Przy braku dostępu do rzetelnej informacji grupy osób zagrożonych stereotypem, ale również grupy tworzące stereotyp nie są w stanie poprawnie łączyć informacji czy się nimi wymieniać. Dzięki temu przecież mogliby zweryfikować określone osądy.

Powyższa kwestia ma związek z faktem, że wyznawane wartości są ważniejsze aniżeli poczucie przynależności do grupy. W takim przypadku to religia łączy podobnych sobie ludzi, a nie wspólne miejsce zamieszkania. Jeśli jednak jednostka zostaje porzucona przez grupę, wówczas jest zdolna do zmiany wyznawanych wartości, by zyskać poczucie przynależności do grupy. Wiąże się to z afiliacją, która jest niezbędna do prawidłowego rozwoju, zwłaszcza osób młodych. Stąd tak wiele trudności mają rodzice z dorastającymi dziećmi, dla których wielokrotnie ważniejsi są rówieśnicy.

Zagrożenie stereotypem prowadzi do negatywnego myślenia, które z kolei - prowadzi do obniżenia poziomu wykonywanych zadań. Po przeprowadzeniu badań badacze uznali, że lęk związany z zagrożeniem stereotypem nie występuje bezpośrednio po manipulacji zagrożeniem, ale jest opóźniony, co tłumaczy wyniki ich badań.

\section{Migracja w Unii Europejskiej a tworzenie się tożsamości kulturowej}

Identyfikacja imigrantów osiedlających się w krajach europejskich ze zbiorowością i kulturą kraju pochodzenia jest czynnikiem często niedo-

11 E. Aronson, T.D. Wilson, R.M. Alert, Psychologia społeczna. Serce i umyst, Poznań 1997, s. 543.

12 S. Bedyńska, P. Rycielski, Kim jestem? Przeciwdziałanie stereotypizacji i stygmatyzacji osób z ograniczeniami sprawności, Warszawa 2010, s. 89. 
cenianym lub celowo ignorowanym w toku tworzenia polityki migracyjnej państw europejskich. Najczęściej wybierane przez państwa przyjmujące strategie wobec bliskowschodnich imigrantów to przymusowa asymilacja lub separacja, która w warunkach skrajnych prowadzi do alienacji i wykluczenia jednostek mających trudności z adaptacją. Taktyki akulturacyjne przyjmowane przez państwa przyjmujące wobec imigrantów z Bliskiego Wschodu skutecznie pomijają model integracyjny, który nie wymagałby od społeczności imigranckich zastąpienia kultury kraju pochodzenia systemem wartości kraju destynacji, a w procesie wzajemnego przystosowania modyfikowałby dotychczasowe schematy przyjmowane zarówno przez przyjmujących, jak i przez przybyszów. Model ten okazuje się jednak najtrudniejszy do zrealizowania, a ocena efektywności podjętych w jego ramach działań jest najbardziej odsunięta w czasie, przez co staje się on najmniej atrakcyjnym sposobem „radzenia sobie” z imigrantami z punktu widzenia osiągnięcia politycznego sukcesu ${ }^{13}$.

Według badania porównawczego przeprowadzonego w 2014 roku w 34 uprzemysłowionych krajach świata, którego wyniki opublikowała Fundacja Bertelsmanna, najistotniejszymi czynnikami decydującymi o stopniu spójności społecznej są: relacje społeczne między jednostkami, emocjonalne przywiązanie do zbiorowości i poczucie odpowiedzialności za interes publiczny. Jak się okazuje, liczebność imigrantów w danym kraju nie ma wpływu na poziom spójności jego społeczeństwa - dużo większe znaczenie ma tu bowiem poziom tolerancji i akceptacji różnorodności, który kształtuje stosunki między jednostkami i buduje zaufanie współmieszkańców ${ }^{14}$.

Wyniki badania są jednoznaczne: kraje przyjmujące największą liczbę imigrantów (Kanada, Australia, Szwajcaria, Niemcy) mają najwyższy wskaźnik społecznej spójności. W Bułgarii, Rumunii i Polsce, gdzie liczba imigrantów jest niewielka, wskaźnik spójności społecznej jest najniższy. Badanie to podważa także argumenty zwolenników wartości konserwatywnych, według których to głównie wspólna religia i doświadczenie kulturowe gwarantują społeczną spójność. Okazuje się bowiem, że w krajach,

13 H. Mamzer, Tożsamość w podróży, [w:] Wielokulturowość a ksztattowanie tożsamości jednostki, red. H. Mamzer, Poznań 2002, s. 165.

14 D. Kubacka-Jasiecka, Zmiany tożsamości w przebiegu zmagania się z kryzysem emocjonalnym, [w:] Człowiek wobec zmiany: rozważania psychologiczne, red. D. Kubacka-Jasiecka, Kraków 2002, s. 106. 
w których badany wskaźnik jest najwyższy, religia nie wpływa znacząco na emocjonalne przywiązanie obywateli do własnej zbiorowości. W krajach, w których religia jest jedną z wartości fundamentalnych, wskaźnik spójności społecznej jest najniższy. Warto przytoczyć w tym miejscu rezultaty badania ${ }^{15}$.

Unia Europejska i jej sąsiedzi przeprowadzili badania w 25 krajach członkowskich Wspólnoty w 2006 roku. Wynika z niego, że wspólne dziedzictwo kulturowe jest najrzadziej wskazywaną przez respondentów wartością, z którą utożsamiają wspólnotę europejską. Najwięcej wskazań otrzymały: demokracja, prawa człowieka, pokój i wolny rynek. Unia Europejska jest więc dla swych obywateli nie tylko polityczno-gospodarczym związkiem państw, ale przede wszystkim unią łączącą swoich mieszkańców ideą, systemem określonych zasad, wizją świata otwartego dla wszystkich tych, którzy podzielają i chcą wspólnie realizować wymienione wartości. I jak wynika z przytoczonych powyżej badań oraz innych analiz, jest w niej miejsce także dla imigrantów ${ }^{16}$.

\section{Tożsamość zbiorowa muzułmanów w UE - szansa czy zagrożenie?}

Młodzież imigrancka przyjmuje również cechy i wartości europejskie, w której żyje. Do najważniejszych z nich należą wspólny język oraz wspólna działalność społeczna w szkołach. Mimo tego, że czują się obcokrajowcami, udaje im się otrzymać obywatelstwo kraju, w którym żyją.

Imigranci przybywający do Europy, którzy cierpią z powodu szoku kulturowego, często stają się radykalni. $Z$ tego powodu społeczeństwo odrzuca i nie akceptuje ich występowania w danym środowisku. Oni też nie akceptują państwa świeckiego, więc naturalnie takie osoby wkraczają na drogę radykalizmu. Odnajdują siebie w grupach ekstremistycznych, które ich utrzymują. W 2003 roku niemiecki rząd wprowadził zakaz działalności radykalnej islamskiej Partii Wyzwolenia. Jednak w Europie skrajna prawica rośnie w siłę i jest coraz bliżej do zdobycia władzy ${ }^{17}$.

\footnotetext{
15 Ibidem, s. 108.

16 A. Jawłowska (red.), Wokół problemów tożsamości, Warszawa 2001, s. 310.

17 M. Ruhs, W. Eskil, A. Wójcicka, op.cit., s. 144-145.
} 
Islamiści dążą do zaznaczenia swojej obecności w Europie i odmawiają przystosowania się do społeczeństwa europejskiego. Istnieje podział na muzułmanów i Europejczyków w stosunku do tego, w jaki sposób rozwiązuje się sprawy islamu. Stanowi to sztuczne rozwiązanie prowadzące do negatywnych skutków. Prowadzi to do zakorzenienia i sprzecznych poglądów na temat kwestii tożsamości. Może to powodować konflikty i sprzeczności. To konfliktogenne zjawisko powinno znaleźć odpowiednie rozwiązanie w duchu zadowalającego kompromisu. Trzeba też pamiętać, że w UE, która związana jest silną tożsamością zbiorową, ten stan rzeczy może spowodować zaniepokojenie oraz zwrot ku nacjonalizmowi z powodu strachu i nienawiści ${ }^{18}$.

Z kolei czynnik tożsamości w UE będzie coraz bardziej obecny na scenie politycznej. Imigranci muzułmańscy będą mieli większy wpływ, jeżeli będą bardziej uczestniczyć w wyborach politycznych. Która partia polityczna poradzi sobie z tym czynnikiem, z problemem Salmana Rushdiego, hidżabów i tożsamości? Obecnie muzułmanie stanowią wyzwanie dla wewnętrznej jedności społecznej. Czynnik islamski będzie też obecny w polityce zagranicznej UE:

1. Aktywność imigrantów jest coraz bardziej widoczna - wspólnota muzułmańska w Londynie (liczba muzułmanów wynosi ponad milion) razem $\mathrm{z}$ koalicją organizacji nawołujących do zaprzestania wojny w Iraku organizowała protesty. Były to największe protesty w historii Wielkiej Brytanii. Odbyły się pod hasłem „Stop wojnie w Iraku. Wolność dla Palestyny".

2. Sąsiedztwo z UE - istnieje wiele krajów muzułmańskich sąsiadujących z Europą. Skierowanie uwagi na czynnik muzułmański w polityce zagranicznej wynika z uzależnienia Europy od źródeł energii, tj. od niektórych krajów Bliskiego Wschodu ${ }^{19}$.

Pragnę nawiązać do rozpatrywanego zagadnienia także na podstawie badań własnych przeprowadzonych na grupie 20 osób, które w latach 2015-2016 zamieszkiwały w Polsce i Niemczech. Ze względu na specyfikę tematu badana grupa była zróżnicowana pod względem wyznania, wieku oraz

\footnotetext{
18 Ibidem, s. 148.

19 Ibidem, s. 152.
} 
płci. Łączyło ich wspólnie pochodzenie - Bliski Wschód, język arabski, narodowość arabska, kultura. Należy zauważyć, iż dość liczna grupa imigrantów określa swoją tożsamość głównie przez pryzmat identyfikacji etnicznej. Respondent identyfikuje siebie jako Araba z Iraku, z Syrii czy z Jemenu, a powinien określić swoją narodowość jako arabską, ponieważ pytanie dotyczyło narodowości, a nie obywatelstwa. Zatem czynnik ten odgrywa kluczową rolę w ich identyfikacji. Każdy Arab mówi w języku arabskim, już sam język tworzy ważną więź. Podobnie sprawa ma się przy odpowiedziach na pytanie odnoszące się do obywatelstwa. Większość respondentów stwierdziła, że jest przywiązana do pierwotnego obywatelstwa i czuje się Irakijczykami, Syryjczykami czy Jemeńczykami. Nawiązuje do obywatelstwa w wymiarze historycznym, kulturowym, społecznym i językowym, a nie do obywatelstwa w wymiarze politycznym. Jednak w tych krajach arabskich panuje represyjność rządów, co kłóci się z koncepcją polityczną obywatelstwa. Powinno to odzwierciedlić się w postaci naturalnej reakcji na dyskryminację i prześladowania obywateli przez rządy tych krajów. Pozostałe osoby objęte badaniem wskazały w swoich odpowiedziach, że mają przynależność i poczucie obywatelstwa kraju przyjmującego. To uczucie przychodzi przez nabycie praw w kraju przyjmującym, jeśli chodzi o prawo do zamieszkania, edukacji, zatrudnienia i udziału w życiu politycznym. Poczucie obywatelstwa państwa przyjmującego pojawia się ze względu na prawa i obowiązki uzyskane nie z powodu przynależności etnicznej czy narodowej do tych państw. Tutaj respondent czuje się obywatelem tego państwa i gotów jest go bronić, ale nie jest w stanie zrezygnować z pierwotnego obywatelstwa, którego podstawą są więzi etniczne, historyczne i kulturowe.

Odpowiedzi na pytanie dotyczące czynników samoidentyfikacji potwierdzają, że przynależność etniczna i religijna ma istotną rolę. Na pewno religia jest czynnikiem koniecznym do identyfikacji dla większości respondentów. To wynika z niektórych wywiadów, które prowadziłem. $\mathrm{Na}$ przykład w jednym wywiadzie pewien imam stwierdził, że „dla muzułmanów sytuacja różni się $\mathrm{w}$ porównaniu $\mathrm{z}$ wyznawcami innych religii. $\mathrm{Mu}-$ zułmanin patrzy przede wszystkim na tożsamość religijną. Wziął na siebie islam jako religię, Allaha jako Boga, a Mahometa jako proroka, więc jego tożsamość jest religijna, a ona samoidentyfikuje jego tożsamość i osobowość. Określa, kim on jest. Islam określa naszą osobowość. My, muzuł- 
manie, jesteśmy rządzeni przez religię, natomiast inne czynniki odgrywają mniejszą rolę".

W odpowiedzi na pytanie dotyczące celu migracji większość respondentów stwierdziła, że podjęła się migracji w poszukiwaniu lepszego życia dla siebie i swojej rodziny, pomimo że kraj przyjmujący różni się od kraju pochodzenia kulturalnie, społecznie i politycznie.

Celem głównym jest sprowadzenie ich rodzin do kraju przyjmującego. Zamierzają uzyskać tu stały pobyt. Osoby, które zdecydowały się na migrację z powodów politycznych czy bezpieczeństwa, mają więcej problemów w życiu społecznym i ekonomicznym.

Na pytanie o stopień zgodności pracy z kwalifikacjami wielu respondentów odpowiedziało, że praca nie jest zgodna z ich kwalifikacjami. Mimo to nie narzekają.

Jeśli chodzi o pytanie dotyczące organizacji społeczno-polityczną, badana grupa odznacza się małą przynależnością do takich organizacji, szczególnie było to widoczne u osób z niskim wykształceniem. Osoby z wyższym wykształceniem są bardziej aktywne w tych organizacjach. Zdecydowana większość zgadza się, że organizacje które zostały stworzone przez imigrantów, mają duży wpływ na zachowanie ich kultury i wartości przez organizowane wydarzenia kulturowo-społeczne, narodowe i religijne.

Na pytanie, czy imigranci chcą wychowywać dzieci w kulturze kraju pochodzeniu, czy kraju, w którym mieszkają, odpowiedzi były podobne. Większość z nich chce wychowywać swoje dzieci w kulturze kraju pochodzenia. Uważają, że ich dzieci powinny pamiętać o swojej tradycji. Uważają, że wartości nowej kultury nie są im bliskie, zaś niektóre osoby uważają, że są im wręcz obce. W niektórych odpowiedziach respondenci wyrazili opinię, że ich dzieci mają utrzymywać swoją tradycję i przyjmować od nowej kultury tylko to, co najlepsze. Deklarując, że religia jest ważnym czynnikiem samoidentyfikacji, chcą wychowywać swoje dzieci zgodnie z wartościami islamu i mogą przyjmować od nowej kultury tylko to, co jest zgodne z ich religią.

Podsumowując, jak wynika z badań własnych autora, najważniejszą identyfikacją imigrantów jest identyfikacja oparta na przynależności etnicznej i religijnej, w mniejszym stopniu państwowej. W nowym środowisku o wiele lepiej odnalazły się osoby emigrujące ze względów ekonomicznych niż politycznych oraz te, które posiadają wyższe wykształcenie. 
Osoby te również częściej niż inne deklarują, że kultura europejska staje się istotnym składnikiem ich tożsamości.

\section{Podsumowanie}

Sekularyzacja islamu w Europie oznacza tworzenie spersonalizowanych jednostek łączących kulturę zachodnią i islamską. W tym celu należy popierać „euroislam”, który przyjmuje konieczne reformy w kierunku integracji europejskiej, a zarazem uznaje możliwość zachowania własnej tożsamości. Jest to korzystne także w celu stymulacji społeczeństw europejskich do przyjmowania i integrowania imigrantów, żeby mieli możliwość zakorzenienia się w Europie.

Każda ze stron potrzebuje potwierdzenia swojej tożsamości. Muzułmańscy imigranci muszą akceptować normy, tradycje i kulturę każdego państwa europejskiego, w którym żyją. Europejczycy potrzebują rozszerzenia swojej perspektywy, jej adaptacji i pogodzenia się z pluralizmem kulturowym w kierunku akceptacji imigrantów, a nie ich asymilacji. Dialog musi przebiega między umiarkowanymi reprezentantami każdej kultury.

mgr Dalzar Nashwan Salem

Wydział Nauk Politycznych i Studiów Międzynarodowych

Uniwersytet Warszawski

ul. Krakowskie Przedmieście 26/28, 00-927 Warszawa

sdalzar@gmail.com

\section{Bibliografia}

Aronson E., Wilson T.D., Alert R.M., Psychologia społeczna. Serce i umyst, Poznań 1997.

Białowąs A., Filozoficzne aspekty wykorzystywania informacyjno-komunikacyjnych technologii w procesie ksztatcenia i samoksztatcenia, [w:] Nowe media a tradycyjne środki przekazu, red. P. Drzyzga, Kraków 2007.

Bedyńska S., Rycielski P., Kim jestem? Przeciwdziałanie stereotypizacji i stygmatyzacji osób zograniczeniami sprawności, Warszawa 2010.

Bokszański Z., Tożsamość zbiorowa, Warszawa 2007. 
Golka M., Czym jest tożsamość?, http://socjologia.amu.edu.pl/isoc/userfiles/33/Czym_jest_tozsamosc.pdf.

Grabowska I., Movers and Stayers: Social Mobility, Migration and Skills, Frankfurt am Main 2016.

Kubacka-Jasiecka D., Zmiany tożsamości w przebiegu zmagania się z kryzysem emocjonalnym, [w:] Człowiek wobec: rozważania psychologiczne, red. D. Kubacka-Jasiecka, Kraków 2002.

Mamzer H., Tożsamość w podróży, [w:] Wielokulturowość a kształtowanie tożsamości jednostki, red. H. Mamzer, Poznań 2002.

Paluchowski W., Internet a psychologia. Możliwości i zagrożenia, Warszawa 2009.

Pawliczuk W., Koncepcje antropologiczno-kulturowe adolescencji, „Postępy Nauk Medycznych" 2006, nr 6.

Ruhs M., Eskil W., Wójcicka A., Labour Migration. What's in it for us? Experiences from Sweden, the UK and Poland, Stockholm 2012.

Sobecki M., Wielowymiarowa tożsamość kulturowa a egzystencja człowieka w kontekście edukacji międzykulturowej, [w:] Edukacja międzykulturowa w Polsce na przełomie XX i XXI wieku, red. A. Paszko, Kraków 2004.

Steel A.E., Stereotype threat and the intellectual test performance of African American, "Journal of Personality and Social Psychology” 1994, Vol. 5, No. 69.

Wokót problemów tożsamości, red. A. Jawłowska, Warszawa 2001.

\title{
The collective identity of immigrants from the Middle East in EU countries
}

\begin{abstract}
Identity is one of the forms of belonging to specific cultural groups. By that, the individual becomes a member of the larger community. It means that individuals can integrate with each other, act as each other's specific features. And what is more important to them, all the standards they adopt are the same. In the circumstances, whereas many social groups are forced to leave their countries, their respective objectives are different. Some are leaving for work, some avoiding wars or persecution, and others want to improve their living conditions. This forces us to undertake in-depth analyses of the situation, because the members of other
\end{abstract}


countries are not always favourably disposed to accept foreigners. In the case of people from the Middle East concerns are stronger; the more Europe is struggling with the wave of terrorism. This raises additional concerns. These are strong enough, that it erases the advantages of the influx of foreign labour for an ageing community. Of course Europe undertakes appropriate actions to help the immigrant population. None the less fears are strong enough to block the appreciation of the advantages of this potential.

Keywords: Middle East, collective identity, the European Union

\section{Комективная идентичность иммигрантов с БАижнего Востока в странах Европейского Союза}

\section{Абстракт}

ИАентичность явАяется оАной из форм принаАлежности к опреАеленным культурным группам. Из-за чего социальная еАиница становится чиеном большего сообщества. В то же время Аичность может интегрироваться с Аругими АюАьми, выполнять взаимно определенные функции. И то, что Аля них наиболее важно, принимать те же нормы и позиции. ОАнако многие социальные группы просто вынуждены покинуть свои страны. Причины могут быть очень разные. ОАни выезжают в поисках работы, Аругие из-за преследований, иные хотят укучшить условия жизни. Все это побужАает к глубокому анализу ситуации, поскольку преАставители Аругих стран не

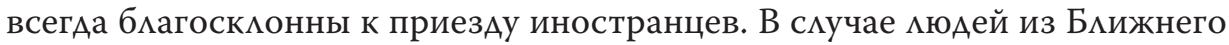
Востока эти опасения еще более усиликись, так как Европа борется с волной терроризма. Это вызывает дополнительные проблемы и беспокойства. Они настолько сильны, что мы не замечаем преимуществ, которые следуют из-за притока иностранной рабочей силы Аля стареющего общества. Европа, безусловно, принимает соответствующие меры Аля того, чтобы помочь иммигрантам. ОАнако эти опасения настолько сильны, что мы все еще не можем полностью использовать этот потенциал.

КАючевые слова: БАижний Восток, колмективная идентичность, Европейский союз 